\title{
Inheritance of Resistance to Head Smut Disease in Corn
}

\author{
Akhtar Ali ${ }^{1}$ and James R. Baggett \\ Department of Horticulture, Oregon State University, Corvallis, OR 97331 \\ Additional index words. Zea mays, Sphacelotheca reiliana, vegetable breeding
}

\begin{abstract}
The inheritance in corn (Zea mays L.) of resistance to head smut disease incited by Sphacelotheca reiliana (Kuhn) Clinton was studied in the field on crosses of resistant dent corn line N6 with two susceptible sweet corn ( $\left.s u_{1}\right)$ inbred lines. Disease incidence in the resistant parent (Pr) was $0 \%$ to 4\%, and $83 \%$ to $96 \%$ in the susceptible parent (Ps). Predisposition of seedlings by clipping just above ground level increased percent infected in progeny populations by as much as 4-fold, but did not affect disease incidence in the, parents. At the lower disease incidence of unclipped plots, the $\mathrm{F}_{1}, \mathrm{~F}_{2}$, and $\mathrm{BCr}$ means were close to the mean of Pr, suggesting dominance of resistance. At the high disease incidence of clipped plots, the relationship of parent and progeny means "suggested additive inheritance. Epistasis was also generally present with a higher level indicated for unclipped plots. Inheritance was concluded to be quantitative. Reciprocal differences were observed only in backcrosses. In the $F_{2}$ and BCs populations, plants grown from dent $\left(S u_{l}\right)$ seed were lower in disease incidence than plants grown from $s u_{l}$ seed.
\end{abstract}

Head smut, incited by Sphacelotheca reiliana, affects corn, sorghum, and sudan grass (Halisky, 1963). The disease is initiated by infection of seedlings, either through the roots or coleoptile (Kruger, 1962). The mycelium becomes systemically established in the meristem and eventually produces large sori that replace the normal ears and sometimes form in the tassel (Halisky, 1963; Potter, 1914). Because loss of the ear is assured when the seedling is infected, degree of host susceptibility is expressed by disease incidence. Corn cultivars differ in potential for infection under a particular set of conditions that involve environmental factors such as soil moisture, level of smut inoculum in the soil, and host predisposition (Ali and Baggett, 1986; Baggett and Koepsell, 1983; Baier and Kruger, 1962; Halisky, 1963; Mack et al., 1984; Matyac and Kommedahl, 1985). Wide differences in cultivar susceptibility to head smut have been reported (Baggett and Koepsell, 1983; Foster and Frederiksen, 1977; Kruger, 1962; Ma et al., 1983; Stromberg et al., 1984).

Several studies of the inheritance of resistance to head smut have been reported. Mei et al. (1982), in China, reported that the inheritance of resistance is quantitative. In 69 of 85 crosses studied, inheritance was mainly additive, with the $F_{1}$ close to the midparent in disease incidence. In 14 of 85 crosses, disease incidence was higher than in the midparent, and in 2 of 85 crosses, disease incidence was lower than in either parent, indicating resistance was over-dominant. Ma et al. (1983), also in China, reported that resistance was quantitatively inherited and was dominant, recessive, or controlled by the interaction of several non-allelic genes, depending on the parents. Additive gene effects were also important and there was a positive correlation between resistance in the $\mathrm{F}_{1}$ and the parents. Stromberg et al. (1984) found that $F_{1}$ hybrids were intermediate between $\mathrm{Pr}$ and Ps in smut incidence.

Our objective was to elucidate the inheritance of resistance to head smut as expressed by infection incidence in the field under natural conditions but with high infection potential provided by seed furrow inoculation. We also sought to compare

Received for publication 8 Dec. 1988. Oregon Agricultural Experiment Station Technical Paper no. 8727. The cost of publishing this paper was defrayed in part by the payment of page charges. Under postal regulations, this paper therefore must be hereby marked advertisement solely to indicate this fact.

'Present address: Directorate of Pulses, Ayub Agricultural Research Institute, Faisalabad, Pakistan. infection data obtained at high and low levels of infection incidence achieved through predisposition of a portion of the plants by clipping in the seedling stage (Ali and Baggett, 1986). An additional objective was to determine whether there is a relationship between resistance level and sweet vs. dent endosperm type in the genetic background.

\section{Materials and Methods}

The Pr in these studies was Nebraska 6 (N6), an inbred line of $S u_{t}$ endosperm type. Ps were SM7, an early maturing $s u_{l}$ inbred line obtained from Crookham Seed Co. (Caldwell, Idaho), and SD-1, a $s u_{l}$ corn inbred line we derived by self-pollination and selection from the highly susceptible commercial $F_{1}$ hybrid 'Sugar Daddy'. Crossing and selfing of the $F_{1}$ to produce seed were done in either the field or greenhouse using standard methods of pollination control. Crosses were made reciprocally (line to line). Backcrosses $\mathrm{BCs}$ and $\mathrm{BCr}$ were made reciprocally between the $F_{1}$ and $P s$ and between the $F_{1}$ and $P r$, respectively. After determination of the extent of reciprocal differences, reciprocals were combined for genetic analysis.

Parents and progenies were tested at the Oregon State Univ. Vegetable Research Farm in 1982 and 1983. A standard plot consisting of a single row $6 \mathrm{~m}$ long was used in a randomized

Table 1. Relationship of year, clipping treatment, and endosperm type to head smut incidence.

\begin{tabular}{|c|c|c|c|c|}
\hline \multirow[b]{2}{*}{ Comparison $^{2}$} & \multirow{2}{*}{$\begin{array}{l}\text { Uninfected } \\
\text { (No.) }\end{array}$} & \multicolumn{2}{|c|}{ Infected } & \multirow[b]{2}{*}{$x^{2}$} \\
\hline & & Number & Percent & \\
\hline \multicolumn{5}{|l|}{ Year } \\
\hline 1982 & 5,891 & 3,998 & 39.8 & \multirow[t]{2}{*}{$653^{* *}$} \\
\hline 1983 & 14,015 & 4,717 & 25.2 & \\
\hline \multicolumn{5}{|l|}{ Clipping } \\
\hline Unclipped & 11,968 & 3,639 & 23.3 & \multirow[t]{2}{*}{$775^{* *}$} \\
\hline Clipped & 7,938 & 4,976 & 38.5 & \\
\hline \multicolumn{5}{|l|}{ Endosperm type } \\
\hline$\left(S u_{1}\right)$ & 6,634 & 3,303 & 33.2 & \multirow[t]{2}{*}{$122^{* * *}$} \\
\hline$\left(s u_{1}\right)$ & 4,968 & 3,472 & 41.1 & \\
\hline
\end{tabular}

${ }^{2}$ All parents and progenies combined for the year and clipping comparisons. $\mathrm{F}_{2}$ and $\mathrm{BCs}$ combined in the dent-sweet endosperm comparison.

**Significantly related at $P=0.01$; values derived from contingency table $\times^{2}$ test for independence. 
Table 2. Incidence of head smut in unclipped and clipped parents and progenies, endosperm types, and reciprocals combined.

\begin{tabular}{|c|c|c|c|c|c|c|c|c|}
\hline \multirow[b]{3}{*}{ Generation $^{2}$} & \multicolumn{4}{|c|}{1982} & \multicolumn{4}{|c|}{1983} \\
\hline & \multicolumn{2}{|c|}{ Unclipped } & \multicolumn{2}{|c|}{ Clipped } & \multicolumn{2}{|c|}{ Unclipped } & \multicolumn{2}{|c|}{ Clipped } \\
\hline & $\begin{array}{c}\text { No. plants } \\
\text { testedy }\end{array}$ & $\begin{array}{c}\text { Percent } \\
\text { infected }^{\mathbf{x}}\end{array}$ & $\begin{array}{c}\text { No. plants } \\
\text { tested }\end{array}$ & $\begin{array}{c}\text { Percent } \\
\text { infected }\end{array}$ & $\begin{array}{c}\text { No. plants } \\
\text { tested }\end{array}$ & $\begin{array}{c}\text { Percent } \\
\text { infected }\end{array}$ & $\begin{array}{c}\text { No. plants } \\
\text { tested }\end{array}$ & $\begin{array}{l}\text { Percent } \\
\text { infected }\end{array}$ \\
\hline \multicolumn{9}{|c|}{$N 6 \times S D-1$} \\
\hline $\operatorname{Pr}(N 6)$ & 113 & $4.0 \mathrm{a}$ & 94 & $0.0 \mathrm{a}$ & 355 & $1.8 \mathrm{a}$ & 298 & $1.0 \mathrm{a}$ \\
\hline $\mathrm{BCr}$ & 452 & $3.7 \mathrm{ab}$ & 395 & $11.4 \mathrm{~b}$ & 988 & $1.4 \mathrm{a}$ & 863 & $10.2 \mathrm{~b}$ \\
\hline $\mathrm{F}_{1}$ & 117 & $9.3 \mathrm{~b}$ & 125 & $36.2 c$ & 458 & $3.5 \mathrm{ab}$ & 427 & $28.5 \mathrm{c}$ \\
\hline $\mathrm{F}_{2}$ & 885 & $25.6 \mathrm{c}$ & 836 & $40.4 \mathrm{c}$ & 1644 & $8.4 \mathrm{~b}$ & 1388 & $24.9 \mathrm{c}$ \\
\hline $\mathrm{BCs}$ & $\therefore \quad 879$ & $63.6 \mathrm{~d}$ & 759 & $76.6 \mathrm{~d}$ & 1730 & $31.5 \mathrm{c}$ & 1437 & $60.1 \mathrm{~d}$ \\
\hline Ps (SD-1) & 229 & $96.3 \mathrm{e}$ & 161 & $91.3 \mathrm{e}$ & 207 & $90.5 \mathrm{~d}$ & 132 & $93.0 \mathrm{e}$ \\
\hline MP & & 50.2 & & 45.6 & & 46.2 & & 47.0 \\
\hline \multicolumn{9}{|c|}{$N 6 \times S M-7$} \\
\hline $\operatorname{Pr}(\mathrm{N} 6)$ & 113 & $4.0 \mathrm{a}$ & 94 & $0.0 \mathrm{a}$ & 355 & $1.8 \mathrm{a}$ & 304 & $1.0 \mathrm{a}$ \\
\hline $\mathrm{BCr}$ & 482 & $2.8 \mathrm{a}$ & 472 & $10.4 \mathrm{~b}$ & 801 & $1.5 \mathrm{a}$ & 633 & $18.1 \mathrm{~b}$ \\
\hline $\mathrm{F}_{1}$ & 80 & $1.3 \mathrm{a}$ & 82 & $12.5 \mathrm{~b}$ & 458 & $4.5 \mathrm{ab}$ & 366 & $33.3 \mathrm{c}$ \\
\hline $\mathrm{F}_{2}$ & 905 & $22.8 \mathrm{~b}$ & 795 & $40.3 \mathrm{c}$ & 1539 & $8.9 \mathrm{~b}$ & 1254 & $31.3 \mathrm{c}$ \\
\hline $\mathrm{BCs}$ & 860 & $50.2 c$ & 606 & $66.8 \mathrm{~d}$ & 1633 & $33.6 \mathrm{c}$ & 1124 & $61.3 \mathrm{~d}$ \\
\hline Ps (SM-7) & 168 & $90.2 \mathrm{~d}$ & 87 & $83.2 \mathrm{e}$ & 156 & $95.0 \mathrm{~d}$ & 63 & $95.8 \mathrm{e}$ \\
\hline MP & & 47.1 & & 41.6 & & 48.4 & & 48.4 \\
\hline
\end{tabular}

Table 3. Analysis of variance for arcsin-transformed percent head smut infection, comparing generations, years, and clipping vs. no clipping; endosperm types and reciprocals combined.

\begin{tabular}{|c|c|c|c|c|c|}
\hline \multirow[b]{2}{*}{ Source } & \multirow[b]{2}{*}{$\mathrm{df}$} & \multicolumn{2}{|c|}{$\mathrm{N} 6 \times \mathrm{SD}-1$} & \multicolumn{2}{|c|}{ N6 $\times$ SM7 } \\
\hline & & $\begin{array}{c}\text { Mean } \\
\text { squares }\end{array}$ & $\mathrm{F}$ value & $\begin{array}{c}\text { Mean } \\
\text { squares }\end{array}$ & F value \\
\hline Years ${ }^{z}$ & 1 & 869.5 & $9.95^{*}$ & 32.4 & $0.37^{\mathrm{NS}}$ \\
\hline Replication within years & 6 & 87.4 & $2.79^{*}$ & 88.3 & $2.05^{\mathrm{NS}}$ \\
\hline Generations & 5 & $11,007.1$ & $78.53 * *$ & $10,991.4$ & $42.04^{* *}$ \\
\hline Clipping & 1 & $1,482.3$ & $6.27^{\mathrm{NS}}$ & $2,004.2$ & $8.57^{\mathrm{NS}}$ \\
\hline Years $\times$ generations & 5 & 140.2 & $4.48^{* *}$ & 261.4 & $6.09^{* *}$ \\
\hline Years $\times$ clipping & 1 & 236.4 & $7.55^{* * *}$ & 233.9 & $5.44^{*}$ \\
\hline Generations $\times$ clipping & 5 & 369.6 & $11.81^{* *}$ & 383.2 & $8.92 * *$ \\
\hline Year $\times$ generation $\times$ clipping & 5 & 9.05 & $0.29^{\mathrm{NS}}$ & 2.0 & $0.05^{\mathrm{NS}}$ \\
\hline Error & 66 & 31.30 & & 43.0 & \\
\hline Total & 95 & & & & \\
\hline
\end{tabular}

${ }^{z}$ Replications within years used as error term to test years.

NS,*,**Nonsignificant or significant at $P=0.05$ or 0.01 , respectively.

complete-block design with four replications. Number of plants per plot varied from 30 to 40 after thinning. All entries in each replication were duplicated to permit clipping (see below) and non-clipping of the seedlings. Clipped and non-clipped plots were randomly distributed. Additionally, generations segregating for dent-sweet endosperm type $\left(\mathrm{F}_{2}\right.$ and $\left.\mathrm{BCs}\right)$ included segregated dent and sweet plots in a paired arrangement. In 1982, the Ps and $\mathrm{F}_{2}$ were planted in double the minimum number of plots to increase population sizes. The reciprocal $F_{1}$ was omitted because of insufficient seed. Thus, in 1982, the number of 6$\mathrm{m}$ plots in each replication was two for $\operatorname{Pr}$ and $\mathrm{F}_{1}$, four for Ps, eight for $\mathrm{BCr}$, and 16 for the $\mathrm{F}_{2}$ and BCs. In 1983, the number of plots of $\operatorname{Pr}, \mathrm{F}_{1}, \mathrm{~F}_{2}$, and backcross plots was increased to three or four times the minimum. Total numbers of plots in 1983 were four Ps, six $\mathrm{Pr}$, eight $\mathrm{F}_{1}, 16 \mathrm{BCr}, 32 \mathrm{~F}_{2}$, and $32 \mathrm{BCs}$ plots in each replication. Data from plots of the same treatment (clip- ping and endosperm type) and from the same replication were pooled for analyses.

Head smut inoculum, consisting of spores bulked from field infections of the previous season, was applied with the seed by means of a V-belt planter. About 0.4 liter of inoculum (50 cc teliospores/liter of slightly dampened vermiculite) was used in each 6-m plot as described by Baggett and Koepsell (1983). Rows were $1.1 \mathrm{~m}$ apart and previously banded with granular fertilizer. General culture, including weed control, was typical of that used in commercial sweet corn in the area, except for irrigation. Immediately after planting, only enough sprinkler irrigation was applied for plant establishment. Irrigation was then avoided during the early stages to enhance infection (Baier and Kruger, 1962; Mack et al., 1984). After the infection period, water was applied as needed to maintain moderate growth.

Plants in the plots designated for clipping were cut off just 
Table 4. Head smut disease incidence in reciprocal backcross progenies of $\mathrm{N} 6 \times \mathrm{SM} 7$ and N6 $\times$ SE- 1 .

\begin{tabular}{|c|c|c|c|c|}
\hline \multirow[b]{2}{*}{$\begin{array}{l}\text { Cross and } \\
\text { generation }\end{array}$} & \multicolumn{2}{|c|}{1982} & \multicolumn{2}{|c|}{1983} \\
\hline & $\begin{array}{c}\text { Infected } \\
(\%) \\
\end{array}$ & $\begin{array}{l}\text { Reciprocal } \\
\text { difference }^{y, x}\end{array}$ & $\begin{array}{c}\text { Infected } \\
(\%)\end{array}$ & $\begin{array}{l}\text { Reciprocal } \\
\text { differencey }\end{array}$ \\
\hline \multicolumn{5}{|l|}{ N6 $\times$ SM7 } \\
\hline $\mathrm{BCr}\left(\mathrm{N} 6 \times \mathrm{F}_{1}\right)$ & 7.9 & $25+$ & 12.5 & 5 \\
\hline $\begin{array}{l}\mathrm{BCr}\left(\mathrm{F}_{1} \times \mathrm{N} 6\right) \\
\mathrm{BCs}\left(\mathrm{SM} 7 \times \mathrm{F}_{1}\right)\end{array}$ & $\begin{array}{r}5.4 \\
64.0\end{array}$ & & $\begin{array}{r}7.0 \\
54.4\end{array}$ & \\
\hline $\mathrm{BCs}\left(\mathrm{F}_{1} \times \mathrm{SM} 7\right)$ & 53.1 & $10.9^{* *}$ & 40.6 & $13.8^{* *}$ \\
\hline $\mathrm{N} 6 \times \mathrm{SD}-1$ & & & & \\
\hline $\mathrm{BCr}\left(\mathrm{N} 6 \times \mathrm{F}_{1}\right)$ & 8.2 & $1.6+$ & 7.8 & $4.1^{* *}$ \\
\hline $\begin{array}{l}\mathrm{BCr}\left(\mathrm{F}_{1} \times N 6\right) \\
\mathrm{BCs}\left(\mathrm{SD}-1 \times \mathrm{F}_{1}\right)\end{array}$ & $\begin{array}{r}6.6 \\
75.2\end{array}$ & & $\begin{array}{r}3.7 \\
50.4\end{array}$ & \\
\hline $\mathrm{BCs}\left(\mathrm{F}_{1} \times \mathrm{SD}-1\right)$ & 65.2 & $10.0+$ & 41.0 & $9.4^{* *}$ \\
\hline
\end{tabular}

${ }^{\mathrm{z}}$ Mean of four replications.

${ }^{y}$ Reciprocal difference tested by $t$ test.

$x+$ Greater than SE.

*,**Significant at $P=0.05$ or 0.01 , respectively.

above ground level when four or five leaves were visible Almost all of these clipped plants recovered and grew to maturity.

Infection incidence was determined at crop maturity when disease symptoms were fully expressed. A plant was counted as infected if sori were found on an ear or tassel. There was no attempt to classify symptoms by severity or type on individual plants.

Genetic parameters were estimated by means of a three-parameter joint scaling test adapted by Rowe and Alexander (1980) from a method described by Cavalli (1952) and Mather and Jinks (1971). The test involves weighted least squares, where the weights are the reciprocals of the SE of the generation means.

\section{Results and Discussion}

The incidenc of head smut was satisfactory in both 1982 and 1983 for differentiation of resistant and susceptible genotypes. Overall disease incidence was higher in 1982 than in 1983 and higher in clipped than in unclipped plots as shown for the crosses and generations combined (Table 1). High $x^{2}$ values from contingency table tests indicated that year and clipping treatments were not independent of disease incidence. In the $\mathrm{F}_{2}$ and BCs, plants with $s u_{l}$ endosperm had significantly higher infection incidence than plants with $s u_{l}$ endosperm.

The Pr ranged from $0 \%$ to $4 \%$ infected, while the Ps were $83 \%$ to $96 \%$ infected. Disease incidence of the parents was only slightly and inconsistently affected by year and clipping, while all progeny generations of each cross were greatly affected (Tables 2 and 3 ). $F$ values for the interactions years $\times$ generations and clpping $\times$ generations were significant at $P=0.01$, but small relative to $\mathrm{F}$ values for generation. The significant interactions were due to differences in magnitude of generation means with year and clipping treatment, but did not involve a change in rankings.

Reciprocals of the $\mathrm{F}_{1}$ and $\mathrm{F}_{2}$ populations were not significantly different in percent infection and were combined in each case for data presentation. Significant differences existed among some reciprocal backcrosses. In backcrosses to Pr or Ps incidence of infection was generally higher when the original parent was used as female than when the $F_{1}$ was used (Table 4). These differences were possibly related to seedling vigor as affected by the seed parent. Because the reciprocal differences were not considered likely to affect the overall interpretation of inheri-

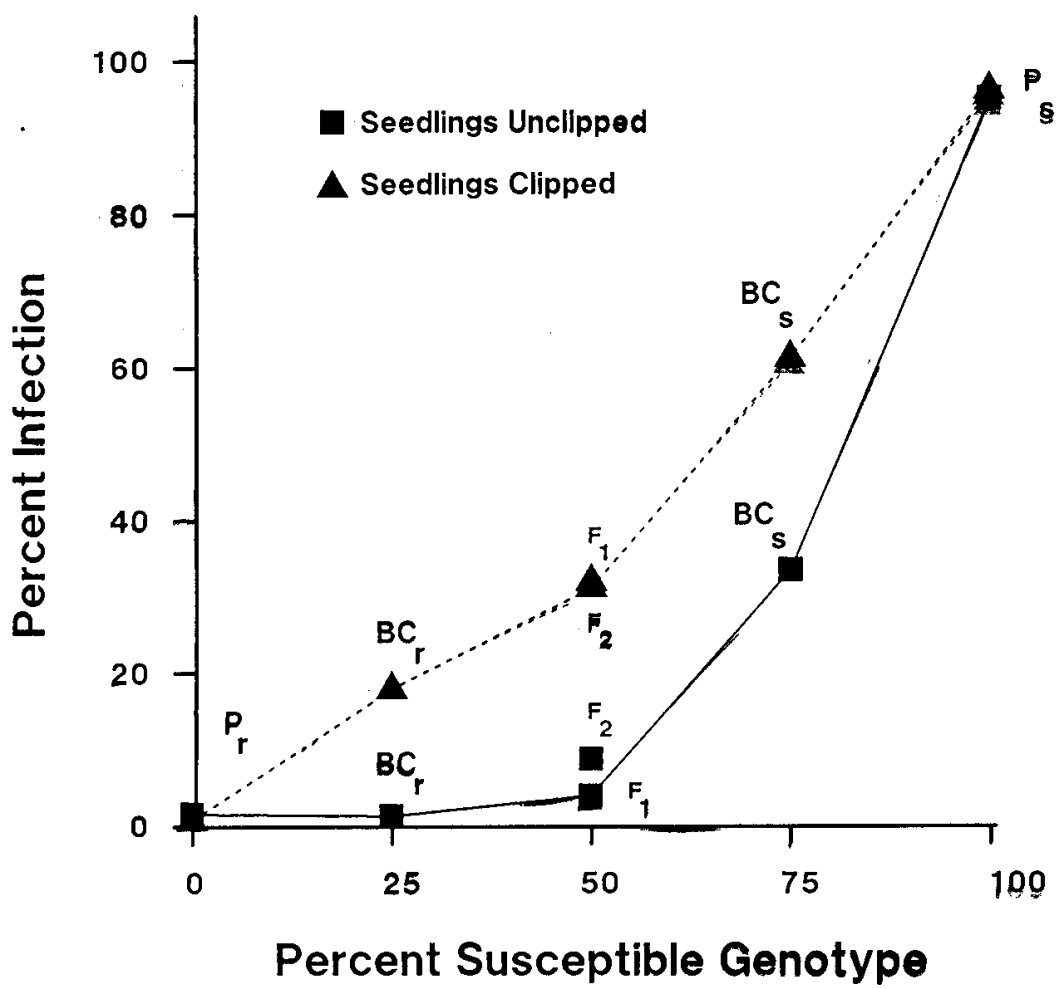

Fig. 1. Incidence of corn head smut among the means of parents and progenies of $\mathrm{N} 6 \times \mathrm{SM} 7$ seedlings, unclipped and clipped, in relation to the percentage of susceptible genotype (1983). 
Table 5. Estimates of genetic parameters using joint scaling tests of arcsin-transformed generation means.

\begin{tabular}{|c|c|c|c|c|c|c|}
\hline \multirow[b]{2}{*}{ Cross } & \multirow{2}{*}{$\begin{array}{l}\text { Clipping } \\
\text { treatment }\end{array}$} & \multicolumn{5}{|c|}{ Gene effects ${ }^{z}$} \\
\hline & & Mean & Additive & Dominance & $\chi^{2 y}$ & $P$ \\
\hline & & & 1982 & & & \\
\hline \multirow{2}{*}{ N6 $\times$ SD1 } & Unclipped & $45.4 \pm 3.0$ & $-42.4 \pm 2.55$ & $-29.1 \pm 5.6$ & 9.2 & $0.01-0.05$ \\
\hline & Clipped & $43.2 \pm 3.6$ & $-41.5 \pm 2.6$ & $-6.5 \pm 7.3$ & 8.9 & $0.02-0.05$ \\
\hline \multirow[t]{3}{*}{$\mathrm{N} 6 \times \mathrm{SM} 7$} & Unclipped & $46.6 \pm 3.5$ & $-36.7 \pm 3.1$ & $40.6 \pm 6.1$ & 16.3 & 0.001 \\
\hline & Clipped & $52.0 \pm 4.65$ & $-38.9 \pm 5.1$ & $-29.8 \pm 7.0$ & 29.9 & $<0.001$ \\
\hline & & & 1983 & & & \\
\hline \multirow{2}{*}{ N6 $\times$ SD1 } & Unclipped & $34.9 \pm 5.0$ & $-33.0 \pm 4.5$ & $-30.6 \pm 9.1$ & 38.2 & $<0.001$ \\
\hline & Clipped & $41.2 \pm 2.7$ & $-36.9 \pm 2.7$ & $-10.6 \pm 5.2$ & 9.4 & $0.02-0.05$ \\
\hline \multirow[t]{2}{*}{ N6 $\times$ SM7 } & Unclipped & $33.9 \pm 4.8$ & $-31.1 \pm 4.1$ & $-30.0 \pm 9.2$ & 33.2 & $<0.001$ \\
\hline & Clipped & $37.2 \pm 3.5$ & $-34.7 \pm 3.3$ & $-8.15 \pm 6.4$ & 15.3 & $0.01-0.001$ \\
\hline
\end{tabular}

${ }^{2} \pm=$ SE of the estimate, where applicable.

${ }^{y}$ A1l $\times^{2}$ values indicate significant deviation (at $P=0.05$ ) from an additive-dominance model.

tance patterns, reciprocal backcrosses were combined in all other data analyses.

Inheritance patterns. The relationship of the parents and progeny varied with the level of disease incidence, especially as affected by clipping and, to a much lesser degree, by year (Table 1). The relationship of population means is shown graphically (Fig. 1) for N6 $\times$ SM7 in 1983 (the graph for N6 $\times$ SD-1 would be almost identical). In Fig. 1, a straight-line configuration would indicate that inheritance is entirely additive. Under the lower infection level of the unclipped plots, the relationship of population means showed a pattern expected when resistance is dominant, with the $\mathrm{F}_{1}$ and $\mathrm{BCr}$ mean percent infected almost as low as the mean of Pr and the means of BCS lower than the mid-parent values. In the clipped plots, with the means of both $\mathrm{F}_{1}$ and $\mathrm{F}_{2}$ approaching the mid-parent values and BCs means higher than the mid-parent values, the pattern approached that expected for additive inheritance with slight dominance. This change from a dominance to an additive pattern is related to the low response of the parents at the high and low extreme of the percent infection range compared to the large response of the $\mathrm{F}_{1}, \mathrm{~F}_{2}$, and backcrosses.

Disease incidence was lower in the $\mathrm{F}$, than in the $\mathrm{F}_{2}$ in every case except for clipped N6 $\times$ SM7 in 1983, but the difference was only significant in two cases in 1982 (Table 2). A lower disease incidence in the $F_{1}$ was possibly related to a higher level of seedling hybrid vigor.

The generation means analysis (Table 5) generally agreed with the data presented in Table 2 and represented by the graphically presented generation means of N6 $\times$ SM7, 1983 (Fig. 1). Additive and dominance effects were usually about equal in the unclipped plots. In clipped plots, the additive effects were usually slightly higher than in unclipped, but the dominance effects were much lower. Chi-square values, which indicated possible epistatic effects, were all significant at $P \leq 0.05$ and were usually lower in clipped than in unclipped plots.

Although the expression of resistance and susceptibility in individual plants is qualitative and the frequency distribution for the progenies includes only two classes, genetic control of susceptibility to infection is quantitative. This conclusion is supported additionally by the continuous range of susceptibility found in corn cultivars (Foster and Frederiksen, 1977; Kruger, 1962; Ma et al., 1983; Stromberg et al., 1984). It is important to recognize that the varying disease incidence, as affected by environment and factors that might predispose the corn plant to infection, can influence data interpretation and thus the apparent inheritance pattern in a given test. In this study, the level of disease incidence obtained in the clipped plots probably exceeded levels normally encountered in commercial corn production. Thus, from an economic viewpoint, corn breeders may consider resistance to have a degree of dominance over susceptibility. However, at higher disease levels, the responses of all progenies suggest that additive gene action is predominant and corn breeders should attempt to incorporate as much resistance as possible in all inbred lines to be used as parents in $F_{1}$ hybrids. Selection for the highest levels of resistance should be practiced in early and later generations under high infection levels.

Plant characteristics, such as dent vs. sweet endosperm type, probably can affect susceptibility in an indirect manner through an effect on seedling vigor. However, unpublished cultivar tests done at this station indicate that sweet corn germplasm with high levels of resistance is available.

\section{Literature Cited}

Ali, A. and J.R. Baggett. 1986. Predisposition of corn plants to the head smut disease by clipping for the selection of resistant genotypes. J. Agr. Res. (Pakistan) 24:223-227.

Baggett, J.R. and P.A. Koepsell. 1983. Field inoculation of sweet corn with the head smut pathogen (Sphacelotheca reiliana). HortScience 18:67-68.

Baier, W. and W. Kruger. 1962. Sphacelotheca reiliana of maize. II. Field studies on the effect of soil conditions. South African J. Agr. Sci. 5:183-190.

Cavalli, L. 1952. An analysis of linkage in quantitative inheritance, p. 135-144. In: E.C.R. Reeve and C.H. Waddington (eds.). Quantitative inheritance. Her Majesty's Stationery Office, London.

Foster, J.H. and R.A. Frederiksen. 1977. Symptoms of head smut in maize seedlings and evaluation of hybrids and inbreds. Texas Agr. Expt. Sta. PR 343:1-4.

Halisky, P.M. 1963. Head smut of sorghum, sudan grass, and corn caused by Sphacelotheca reiliana (Kuhn) Clint. Hilgardia 34:287304.

Kruger, W. 1962. ,Sphacelotheca reiliana on maize. I. Infection and control studies. South African J. Agr. Sci. 5:43-56.

Ma, B.Y., Y.L. Li, and S.K. Duan. 1983. Preliminary study on the genetics of resistance to head smut in maize (in Chinese, English summary). Scientia Agr. Sinica 4:12-17.

Mack, H.J., J.R. Baggett, and P.A. Koepsell. 1984. Effects of cultural practice on the incidence of head smut in sweet corn. HortScience 19:77-78.

Mather, K. and J.L. Jinks. 1971. Biometrical genetics. The study of continuous variation. Cornell Univ. Press, Ithaca, N.Y.

Matyac, C.A. and T. Kommedahl. 1985. Factors affecting the devel- 
opment of head smut caused by Sphacelotheca reiliana in corn. Phytopathology 75:577-581.

Mei, Z.B., G.Y. Yu, H.C. Wang, G.D. Hou, and J.Y. Li. 1982. Pattern of inheritance of resistance to head smut in maize (in Chinese). Shanxi Nongye Kexue 11:10-13. [Plant Breeding Abstr. 53-8734.] Potter, A.A. 1914. Head smut of sorghum and maize. J. Agr. Res. 2:339-368.
Rowe, K.E. and W.L. Alexander. 1980. Computations for estimating the genetic parameters on joint-scaling tests. Crop Sci. 20:109-110.

Stromberg, E.L., W.C. Stienstra, T. Kommedahl, C.A. Matyac, and C.E. Windels. 1984. Smut expression and resistance of corn to Sphacelotheca reiliana in Minnesota. Plant Dis. 68:880-884. 